\section{Polymorbidity and heterogeneity of intact bone tissue in patients with malignant and metastatic bone tumors}

\author{
N.K. Ternovoy ${ }^{1}$, \\ O.V. Drobotun', N.N. Kolotilov ${ }^{2}$ \\ R.E. Kavetsky Institute \\ of Experimental Pathology, Oncology \\ and Radiobiology NAS of Ukraine ${ }^{1}$, Kyiv \\ Institute of Nuclear Medicine \\ and Radiation Diagnostics NAMS \\ of Ukraine ${ }^{2}$, Kyiv
}

The classical therapeutic minimally invasive concept of onco-orthopedics (the urgent task of which is to preserve the bone that is affected by the tumor process) is based on medical imaging data, endoprosthetics (the advantage of endoprosthetics is the simultaneous resection of the bone affected by the tumor and early restoration of supporting ability and function of the operated limb [9]), bone grafting and has available and cost-effective resources to increase the treatment effectiveness.

In particular, the treatment of concomitant diseases in patients with malignant and metastatic tumors (for example, stomach cancer, pancreatic cancer) is an important factor in increasing their survival and life quality. This aspect practically doesn't comprise onco-orthopedics $[1,6,12,15,16]$.

Medicine is moving from the epoch of "one chronic disease" to the epoch of "polymorbid medicine" [13]. The term "comorbidity" (from Latin cotogether, morbus - disease) was introduced in 1970 by Professor A. Feinstein (in the process of studying the prospects of cancer treatment in patients with concomitant chronic diseases: coronary heart disease, cerebral arteriosclerosis, pulmonary dysfunction), who understood this as additional clinical conditions that already exist or have arisen against the background of the current disease and are always different from it [14]. Synonyms of the term: multimorbidity, polymorbidity (discussion on the different semantics interpretation of these terms continues today), multifactorial diseases, polypathy, comorbidity, polypathology, double diagnosis, pluripathology $[1,8]$.The coexistence of several diseases in one patient in the domestic literature is described as "combined", "concomitant", "associated" diseases or conditions.

Comorbidity is the coexistence of two and/or more diseases in one patient, pathogenetically and genetically interconnected.

Principal clarification of the term [17]: comorbidity is the combination in one patient of two or more chronic diseases, pathogenetically interconnected or coinciding in time in one patient, regardless of the activity of each of them. There are 3 known forms of human comorbidity: direct comorbidity (syntropy), reverse comorbidity (dystropy) and comorbidity between multifactorial (complex) diseases and Mendelian (monogenic) diseases.

Multimorbidity is a combination of several chronic diseases of various genesis in one patient [5].

Polymorbidity is the presence of several simultaneous diseases (genetically or pathogenetically related or unrelated to one another) in one person in different stages and phases of their development. The division of polymorbidity into multimorbidity and comorbidity very often is only conditional.

Polymorbidity is a broad concept. The relationship of several diseases can be represented by such options: one disease may be the cause of another disease; two diseases may have common risk factors or common pathogenesis mechanisms; two diseases may not have a causal relationship or have only a weak association [19]; one disease can be caused by iatrogenic factors that may be caused by another disease [18].

Polymorbidity is accompanied by higher mortality rates, higher disability rates, side effects of treatment, increased use of the patient's body resources, lower quality of life [11].

Comorbidity, to some extent, affects the entire "trajectory" of the tumor process, starting from the moment of predisposition formation up to the diagnosis is established, treatment requires use of supplemental resources [15]. So, for example, chronic obstructive pulmonary disease (COPD) is described as a part of systemic inflammatory syndrome and is associated with lung cancer, osteoporosis, atherosclerosis progression, and chronic kidney disease (CKD) [8]. The purpose of the article is to demonstrate the association of polymorbidity and intact bone tissues' heterogeneity in patients with malignant and metastatic bone tumors. 


\section{Material and Investigation Methods}

The main group consisted of 63 patients with benign, primary malignant and metastatic bone tumors (table 1): $33(52.4 \%)$ men and 30 women $(47.6 \%)$ aged 25 to 75 years (mean age $51.8 \pm 1.5$ months). Benign tumors were found in $8(50.1 \%)$ men and $8(50.0 \%)$ women, malignant tumors - in $13(52.0$ $\%)$ men and $12(48.0 \%)$ women, metastatic bone lesions - in $12(54.5 \%)$ men and $10(45.5 \%)$ women. 37 patients of the control group were investigated for suspected bones tumor lesions on a multispiral tomograph, but the diagnosis was not confirmed: 20 (54 $\%$ ) men and 17 (46\%) women aged 26-75 years, average age $51.7 \pm 1.5$ months All patients gave informed consent for participation in the study.

\section{Table 1.}

Distribution of patients by clinical diagnoses $(n=63)$.

\begin{tabular}{|l|c|c|}
\hline Clinical diagnosis & abs & \% \\
\hline Benign tumors & 16 & 25,4 \\
\hline Malignant tumors & 25 & 39,7 \\
\hline Metastatic tumors & 22 & 34,9 \\
\hline
\end{tabular}

Histogram analysis of radiographic density (RGD) of the computed tomographic images' texture was carried out by a known method [2]. The heterogeneity coefficient $\mathrm{K}_{1}$ was calculated by the described method [9]. The scale "homogeneity $\rightarrow$ heterogeneity" $\mathrm{K}_{1}$ corresponds to $0.00 \rightarrow 1.00$.

The investigation design did not include the study of the diseases' pathogenetic relationships, and therefore we use the term polymorbidity. To assess the severity of polymorbidity in patients, the CIRS-G system (Cumulitive Illness Rating Scale for Geriatrics) was applied. In the calculation, points corresponding to concomitant diseases are summerized, and also one point is added for every ten years of life when a patient exceeds forty years (that is, 50 years -1 point, 60 years -2 points, etc.) [20].

According to the CIRS-G system, a separate summary assessment of the state of each of the organ systems is carried out: " 0 " corresponds to the absence of diseases of the selected system; "1" - a slight deviation from the norm or past diseases; " 2 " - diseases requiring the drug therapy; " 3 " - a disease that caused disability; "4" - severe organ failure requiring emergency treatment.

The CIRS-G system evaluates polymorbidity by the sum of points, which can vary from 0 to 56, taking into account the age of the patient. According to its developers, maximum results are not compatible with patients being alive. Statistical processing of quantitative indicators was carried out with the package "Microsoft ${ }^{\circledR}$ Excel 97”.

\section{Results and their discussion}

Polymorbidity assessment in persons of the control group and patients with benign, primary malignant and metastatic bone tumors is presented in table 2 .

Only $4(25.0 \%)$ of the 16 patients with benign tumors needed drug therapy for concomitant diseases (arterial hypertension, arthrosis, arthritis, diabetes mellitus 2, cholecystitis).

$8(32 \%)$ of 25 patients with malignant tumors and continuous drug therapy for peptic ulcer, hypertension, chronic venous insufficiency, osteoporosis, consequences of myocardial infarction and ischemic stroke needed, and in $6(24 \%)$ patients the concomitant diseases (myocardial infarction and ischemic stroke) caused disability.

$9(40.9 \%)$ of 22 patients with bone metastases of prostate, breast, lung and kidney cancer, required drug therapy for concomitant diseases (coronary atherosclerosis, coronary heart disease, CKD, COPD, arthrosis, arthritis, diabetes mellitus 2), 13 patients $(59.1 \%)$ the concomitant diseases (myocardial infarction and ischemic stroke) caused disability.

For comparison: more often concomitant diseases are characteristic for malignant tumors of the lungs (58 \%), kidneys (54\%), stomach (53\%), bladder (53 $\%)$ and prostate gland $(51 \%)[1,8]$.

The measurement results of the quantitative characteristics of intact bone tissue on the affected side $3-4 \mathrm{~cm}$ from the tumor site are summarized in table 3 .

Table 2.

Polymorbidity assessment of patients according to the CIRS-G system.

\begin{tabular}{|c|c|c|c|c|c|c|}
\hline \multirow{2}{*}{ Group } & \multirow{2}{*}{ Quant. } & \multicolumn{5}{|c|}{ Polimorbidity, points } \\
\cline { 3 - 7 } & & 0 & 1 & 2 & 3 & 4 \\
\hline Control group & 37 & $15 / 40,5$ & $22 / 59,5$ & - & - & - \\
\hline Benign tumors & 16 & $6 / 37,5$ & $6 / 37,5$ & $4 / 25,0$ & - & - \\
\hline Malignant tumors & 25 & $4 / 16,0$ & $7 / 28,0$ & $8 / 32,0$ & $6 / 24,0$ & - \\
\hline Metastatic tumors & 22 & - & - & $9 / 40,9$ & $13 / 59,1$ & - \\
\hline
\end{tabular}


Table 3.

Bone texture indicators.

\begin{tabular}{|c|c|c|c|c|c|}
\hline \multirow[t]{3}{*}{ № } & \multirow{3}{*}{$\begin{array}{c}\text { Polomorbidity, } \\
\text { level }\end{array}$} & \multicolumn{2}{|c|}{ RGD, HU } & \multicolumn{2}{|c|}{$\mathrm{C} 1$} \\
\hline & & spongy & compact & spongy & compact \\
\hline & & 1 & 2 & 3 & 4 \\
\hline \multicolumn{6}{|c|}{ Control group } \\
\hline 1 & $0-1$ & $319 \pm 16$ & $1381 \pm 45$ & $0,415 \pm 0,012$ & $0,309 \pm 0,010$ \\
\hline \multicolumn{6}{|c|}{ Benign tumors } \\
\hline 2 & $0-1$ & $\begin{array}{c}312 \pm 11 \\
\mathrm{P}_{112}>0,05\end{array}$ & $\begin{array}{l}1175 \pm 26 \\
\mathrm{P}_{212}>0,05\end{array}$ & $\begin{array}{c}0,436 \pm 0,010 \\
P_{312}>0,05\end{array}$ & $\begin{array}{c}0,367 \pm 0,011 \\
\mathrm{P}_{412}<0,02\end{array}$ \\
\hline 3 & 2 & $\begin{array}{c}297 \pm 15 \\
\mathrm{P}_{113}>0,05\end{array}$ & $\begin{array}{c}923 \pm 31 \\
\mathrm{P}_{213}<0,01 \\
\end{array}$ & $\begin{array}{c}0,484 \pm 0,012 \\
\mathrm{P}_{313}<0,05\end{array}$ & $\begin{array}{c}0,401 \pm 0,012 \\
\mathrm{P}_{413}<0,02\end{array}$ \\
\hline \multicolumn{6}{|c|}{ Malignant tumors } \\
\hline 4 & $0-1$ & $\begin{array}{c}278 \pm 10 \\
\mathrm{P}_{114}>0,05\end{array}$ & $\begin{array}{c}993 \pm 21 \\
\mathrm{P}_{214}<0,01 \\
\end{array}$ & $\begin{array}{c}0,542 \pm 0,011 \\
\mathrm{P}_{314}<0,01\end{array}$ & $\begin{array}{c}0,443 \pm 0,011 \\
\mathrm{P}_{414}<0,01\end{array}$ \\
\hline 5 & $2-3$ & $\begin{array}{c}223 \pm 14 \\
\mathrm{P}_{115}<0,01 \\
\end{array}$ & $\begin{array}{c}790 \pm 33 \\
\mathrm{P}_{215}<0,01 \\
\end{array}$ & $\begin{array}{c}0,597 \pm 0,016 \\
\mathrm{P}_{315}<0,01\end{array}$ & $\begin{array}{c}0,481 \pm 0,013 \\
P_{415}<0,01\end{array}$ \\
\hline \multicolumn{6}{|c|}{ Metastatic tumors } \\
\hline 6 & $2-3$ & $\begin{array}{c}204 \pm 16 \\
\mathrm{P}_{116}<0,01\end{array}$ & $\begin{array}{c}784 \pm 34 \\
\mathrm{P}_{216}<0,01 \\
\end{array}$ & $\begin{array}{c}0,626 \pm 0,015 \\
P_{316}<0,01\end{array}$ & $\begin{array}{c}0,533 \pm 0,016 \\
P_{416}<0,01\end{array}$ \\
\hline
\end{tabular}

In early stage tumors, polymorbidity of level 0-1 does not affect the RGD of bone tissues, level 2 is associated with reliably reduced RGD of only compact tissue (compared with the control group). At the same time, $\mathrm{K}_{1}$ was reliably increased with polymorbidity level 0-1 in compact tissue, level 2 - in spongy and compact tissues (compared with the control group).

In malignant tumors, polymorbidity of the level 0-1 is associated with reliably reduced RGD of only compact tissue (compared with the control group) and an increase in the texture heterogeneity of compact and spongy tissue according to the values of $\mathrm{C}_{1}$ (compared with the control group), level 2-3 - with reliably reduced RGD of compact and spongy tissue and an increase in the heterogeneity of their texture according to $\mathrm{C}_{1}$ values (compared with the control group).

In metastatic bone tumors, polymorbidity of level 2-3 is associated with reliably reduced RGD of compact and spongy tissue and an increase in the heterogeneity of their texture according to $\mathrm{K}_{1}$ values (compared with the control group).

In the symmetrical skeleton zones, the indicators (RGD and heterogeneity) of the bone tissue texture in order of magnitude corresponded to the ones we described earlier [9].

The texture heterogeneity of computed tomographic images of malignant and metastatic tumors is characteristic practically for tumors of all body tissues of any localization [3].
It is possible to interpret the detected phenomenon within the framework of the tumor field concept [4].

The effect of polymorbidity on physical characteristics, in particular, on RGD and heterogeneity of intact/conditionally intact tissues' texture in patients with malignant and metastatic bone tumors, has hardly been studied in oncorthopedics and radiology.

\section{Conclusion}

Concomitant diseases requiring drug therapy had $25 \%$ of patients with benign bone tumors, $32 \%$ of patients with malignant bone tumors, and $40.9 \%$ of patients with metastatic bone tumors. $24.0 \%$ of patients with malignant bone tumors and $59.1 \%$ of patients with metastatic bone tumors had concomitant diseases that caused disability.

An increase in polymorbidity level is associated with a decrease in RGD and an increase in the texture heterogeneity of computed tomographic images of the spongy and compact bones (the pattern is reliable, $\mathrm{P}<0.01$ ) in the series: practically healthy individuals, patients with benign tumors, patients with malignant tumors, patients with metastatic tumors .

The investigation was performed as part of the planned research work of the Institute of Nuclear Medicine and Diagnostic Radiology of the National Academy of Medical Sciences of Ukraine "To study the diagnos- 
tic images' heterogeneity in the differential diagnosis of malignancies" (state registration No. 0118 U003101).

The authors declare no conflict of interest.

\section{Literature}

1. Анкудинова С. А. Полиморбидные больные в онкологии / С. А. Анкудинова, С. К. Микабекова, А. В. Богданов // Вестник КРСУ. - 2013. - Т. 13. № 11. - С. 35-38.

2. Борисенко А. В. Дистрофически-деструктивные изменения пародонта больных генерализованным парадонтитом: гистографический анализ компьютерных номограмм / А. В. Борисенко, К. Е. Печковский, Н. Н. Колотилов // Современная стоматология. - 2003. - № 4. - C. 60-62.

3. Колотилов Н. Н. Гетерогенность компьютернотомографических изображений опухолей: введение в проблему / Н.Н. Колотилов // Лучевая диагностика, лучевая терапия. - 2018. - №1. - С. 73-77.

4. Колотилов Н. Н. Неопределённость радиологической идентификации злокачественной опухоли / Н. Н. Колотилов, Т. А. Малышева // Лучевая диагностика, лучевая терапия. - 2016. - №4. - С. 76-82.

5. Лазебник Л. Б., Верткин А. Л., Конев Ю. В. Старение: профессиональный врачебный подход (Национальное руководство) / Лазебник Л. Б., Верткин А. Л., Конев Ю. В. - М.: Эксмо, 2014. 320 с.

6. Макулбекова С. К. Полиморбидность у онкологических больных: дисс. ... кандидата мед. наук: 14.01 .12 / Макулбекова Сандугаш Керимбаевна; [КыргызскоРоссийский Славянский университет], 2017. 184 с.

7. Пузырев В. П. Генетические основы коморбидности у человека / В. П. Пузырев // Генетика. -2015. - T. 51, № 4. - C. 491-502. https://doi.org/10.7868/ S0016675815040098.

8. Тарловская Е. И. Проблема полиморбидности вызов современной медицине / Е. И. Тарловская // Терапия.-2017.-№ 12.-С. 4-14.

9. Текстурный анализ компьютерно-томографических изображений костных тканей: гетерогенность как показатель остеоинтеграции (предварительное сообщение) / Н. К. Терновой, Н. Н. Колотилов, О. В. Дроботун [ и др.] // Лучевая диагностика, лучевая терапия. -2019.-№ 1. - С. 43-50.

10. Чазова И. Е. Коморбидность сердечно-сосудистых и онкологических заболеваний: проблемы диагностики кардиотоксических эффектов химио- и лучевой терапии / И. Е. Чазова, Е. В. Ощепкова, А.Ю. Канторова // Терапевтический архив. - 2015. - № 9. - С. 4-10.

11. Чесникова А. И. Артериальная гипертензия и коморбидность: современное состояние проблемы / А.
И. Чесникова, М. М. Батюшин, В. П. Терентьев // Артериальная гипертензия. - 2016. - Т. 22. - С. 432-440.

12. Aggerholm-Pedersen N. Comorbidity in adult bone sarcoma patients: a population-based cohort study / N. Aggerholm-Pedersen // Sarcoma. - 2014. 690316. Access doi:10.1155/2014/690316. https:/doi. org/10.1155/2014/690316.

13. Aging and multimorbidity: new tasks, priorities, and frontiers for integrated gerontological and clinical research / Fabbri E., Zoli M., Gonzalez-Freire M. [ et al.] // J. Am. Med. Dir. Assoc. - 2015. - Vol. 16(8). - 640-647. https://doi.org/10.1016/j.jamda.2015.03.013.

14. Feinstein A. R. Pre-therapeutic classification of co-morbidity in chronic disease / A. R. Feinstein // J. Chron. Dis. - 1970. - Vol. 23. - P. 455-468. https://doi. org/10.1016/0021-9681(70)90054-8.

15. Geraci J. M. Comorbid disease and cancer: the need for more relevant conceptual models in health services research / J. M. Geraci, C. P. Escalante, J. L. Freeman // J. Clin. Oncol. — 2005. — Vol. 23. — P. 7399-7404. https:// doi.org/10.1200/JCO.2004.00.9753.

16. Gurney J. The impact of patient comorbidity on cancer stage at diagnosis / J. Gurney, D. Sarfati, J. Stanley // Br J Cancer. — 2015. - Vol. 113. - P. 1375-1380. https://doi.org/10.1038/bjc.2015.355.

17. Kraemer H. C. Statistical issues in assessing comorbidity / H. C. Kraemer // Star Med. - 1995. - Vol. 14. - P.721-723.

18. Le Reste J. Y. The European General Practice Research Network presents a comprehensive definition of multimorbidity in family medicine and long term care, following a systematic review of relevant literature/ J. Y. Le Reste, P. Nabbe, B. Manceau // J. Am. Med. Dir. Assoc. - 2013. - Vol. 14. - P. 319-325. https://doi.org/10.1016/j. jamda.2013.01.001.

19. McPhail S. M. Multimorbidity in chronic disease: impact on health care resources and costs / S. M. McPhail // Risk Manag. Healthc. Policy. - 2016. - Vol. 9. -143-56. https://doi.org/10.2147/RMHP.S97248.

20. Miller M. D. Rating chronic medical illness burden in geropsychiatric practice and research: Application of the $\mathrm{Cu}$ mulative Illness Rating Scale / M. D. Miller, C. F. Paradis, P. R. Houck //Psychiatry Research. - 1992. - V.41(3). - P. 237248. https://doi.org/10.1016/0165-1781(92)90005-N.

\section{POLYMORBIDITY AND HETEROGENEITY OF INTACT BONE TISSUE IN PATIENTS WITH MALIGNANT AND METASTATIC BONE TUMORS}

\section{N.K. Ternovoy, O.V. Drobotun, N.N. Kolotilov}

Polymorbidity is the presence of several synchronically occurring diseases (genetically or pathogeneti- 
cally related or unrelated) in one person at different stages and phases of their development, is accompanied by higher mortality rates, higher disability rates, treatment side effects, increased consumption of the patient's body resources, lower quality of life.

The purpose of the article is to demonstrate the association of polymorbidity and intact bone tissues' heterogeneity in patients with malignant and metastatic bone tumors.

Material and methods. 16 patients with benign bone tumors, 25 - with primary malignant bone tumors and 22 - with metastatic bone tumors were investigated with multispiral tomography scanner: 33 $(52.4 \%)$ men and $30(47.6 \%)$ women aged 25 to 75 years. The control group consisted of 37 patients with suspected tumor lesions of the bones, but the diagnosis was not confirmed. To assess polymorbidity in patients, the CIRS-G system was applied.

Conclusion. An increase in polymorbidity level is associated with a decrease in RGD and an increase in the texture heterogeneity of computed tomographic images of the spongy and compact bones (the pattern is reliable, $\mathrm{P}<0.01$ ) in the series: practically healthy individuals, patients with benign tumors, patients with malignant tumors, patients with metastatic tumors.

\section{ПОЛІМОРБЦДНІСТЬ І ГЕТЕРОГЕННІСТЬ КІСТКИ У ХВОРИХ ІЗ ЗЛОЯКІСНИМИ ТА МЕТАСТАТИЧНИМИ ПУХЛИНАМИ КІСТОК}

\section{М.К. Терновой, О.В. Дроботун, М.М. Колотилов}

Поліморбідність - наявність декількох захворювань (пов'язаних або не пов'язаних між собою генетично або патогенетично), що синхронно протікають в однієї людини в різних стадіях і фазах свого розвитку; супроводжується більш високими показниками смертності, більш високими показниками інвалідності, побічними ефектами лікування, підвищеним використанням ресурсів організму хворого, більш низькою якістю життя.

Мета статті - показати асоціацію поліморбідності і гетерогенності кісткових тканин у хворих iз злоякісними та метастатичними пухлинами кісток. Матеріал і методи. Обстежено на мультиспіральному томографі 16 хворих з доброякісними пухлинами кісток, 25 - 3 первинними злоякісними пухлинами кісток і 22 - 3 метастатичними пухлинами кісток: 33 (52,4 \%) чоловіки і 30 жінок $(47,6$ $\%)$ у віці від 25 до 75 років. Контрольна група - 37 пацієнтів з підозрою на пухлинні ураження кісток, але діагноз не був підтверджений. Для оцінки поліморбідності у хворих використовували системy CIRS-G.

Висновки. Збільшення рівня поліморбідності асоціюється зі зменшенням рентгенівської щільності і збільшенням гетерогенності текстури комп'ютерно-томографічних зображень губчастої i компактної кістки (закономірність достовірна, $\mathrm{P}<0,01)$ в ряду: практично здорові особи, хворі 3 доброякісними пухлинами, хворі із злоякісними пухлинами, хворі з метастатичними пухлинами.

\section{ПОЛИМОРБИДНОСТЬ И ГЕТЕРОГЕННОСТЬ ИНТАКТНЫХ КОСТНЫХ ТКАНЕЙ У БОЛЬНЫХ СО ЗЛОКАЧЕСТВЕННЫМИ И МЕТАСТАТИЧЕСКИМИ ОПУХОЛЯМИ КОСТЕЙ}

\section{Н.К. Терновой, О.В. Дроботун, Н.Н. Колотилов}

Полиморбидность - наличие нескольких синхронно протекающих заболеваний (связанных или не связанных между собой генетически или патогенетически) у одного человека в различных стадиях и фазах своего развития, сопровождается более высокими показателями смертности, более высокими показателями инвалидности, побочными эффектами лечения, повышенным использованием ресурсов организма больного, более низким качеством жизни.

Цель статьи - показать ассоциацию полиморбидности и гетерогенности костных тканей у больных со злокачественными и метастатическими опухолями костей.

Материал и методы. Обследовано на мультиспиральном томографе 16 больных с доброкачественными опухолями костей, 25 - с первичными злокачественными опухолями костей и 22 - с метастатическими опухолями костей: 33 (52,4 \%) мужчины и 30 женщин $(47,6 \%)$ в возрасте от 25 до 75 лет. Контрольная группа - 37 пациентов с подозрением на опухолевые поражения костей, но диагноз не был подтвержден. Для оценки полиморбидности у больных использовали систему CIRS-G.

Выводы. Увеличение уровня полиморбидности ассоциируется с уменьшением рентгеновской плотности и увеличением гетерогенности текстуры компьютерно-томографических изображений губчатой и компактной кости (закономерность достоверна, $\mathrm{P}<0,01)$ в ряду: практически здоровые лица, больные с доброкачественными опухолями, больные со злокачественными опухолями, больные с метастатическими опухолями. 